\title{
Liquid-Liquid Extraction and Separation of Zinc (II) With Synergistic Mixture of N-N-Octylaniline and Trioctylamine as an Extractant
}

\author{
${ }^{1}$ Satish N Patkar, ${ }^{2}$ Shrirang D Patil, ${ }^{3}$ Rajgounda J Patil \\ ${ }^{1,2,3}$ Department of Chemistry, Karmaveer Bhaurao Patil College, Vashi, New-Mumbai, Maharashtra, India. \\ 400703.
}

\begin{abstract}
The distribution equilibrium of $\mathrm{Zn}$ (II) between synergistic mixture of $N$-n-octylaniline and trioctylamine in xylene and aqueous acidic thiocyanate media has been investigated as the function of concentration of extractant in organic phase and concentration of hydrogen ion and $\mathrm{Zn}$ (II) ions in aqueous phase. The stoichiometry of the extracted species was determined on the basis of slope analysis. Zn (II) is extracted by the anion exchange mechanism as $\left[\left(\mathrm{RR}^{\prime} \mathrm{NH}_{2}\right)_{2}{ }^{+} \mathrm{Zn}(\mathrm{SCN})_{4}{ }^{2-}\right]_{\text {org }}$ or $\left[\left(\mathrm{R}_{3} \mathrm{NH}\right)_{2}{ }^{+} \mathrm{Zn}(\mathrm{SCN})_{4}{ }^{2-}\right]_{\text {org. }}$. The extraction process is favored due to synergism. It was found that a large number of cations and anions have a high tolerance limit. The selectivity of the extraction is increased by the use of suitable masking agents. The method is extended for the extraction of Zn (II) from synthetic mixture and pharmaceutical sample.
\end{abstract}

Keywords: N-n-octylaniline, Trioctylamine (TOA), Synergistic

\section{Introduction}

Zinc is mostly used in pharmaceutical product, wet batteries, die-casting alloys, light metal alloys galvanizing industry, insecticides, paints and pigments. Zinc is used in metallic coating to improve corrosion resistance of various types of steel. The pickling of steel goods is usually carried out using $20 \% \mathrm{HCl}$ and the process is stopped when $\mathrm{HCl}$ concentration reaches 10\% used CYANEX 921, mixture of 4 trialkylphosphine oxide (CYANEX 923), bis(2,4,4-trimethylpentyl)monothio phosphinic acid CYANEX 302, Alamine336, tri- $n$ octyl phosphineoxide (TOPO) and TBP and concluded that TBP is the best extractant for the recovery of zinc [1]. The tremendous increase in the use of heavy metals over the past few decades has inevitably resulted in an increased flux of metallic substances in the environment. The metals are of special concern because they are non-degradable and, persistent. Therefore, it is essential to remove these elements from industrial effluents and radioactive wastes before discharging into natural water bodies or into land. Zinc is essential part of more than 200 enzymes involved in digestion, metabolism, and reproduction and wound healing. So, zinc is an essential element needed to support the body's immune system.

Most of the extraction of zinc is carried out by using high molecular weight amines. N-n-octylaniline [2] and Aliquat-336-S [3,4] have been used for the extraction and separation of $\mathrm{Zn}$ (II) from acidic media. 2hexyl pyridine in benzene is used to extract zinc from aqueous mineral acid in thiocyanate media [5]. Zinc, Cadmium and Mercury are separated by solvent extraction using thiocarbohydrazide and complexing agent [6]. Solvent extraction separation of $\mathrm{Zn}$ (II), Fe(II), Fe(III) and Cd(II) using tributylphosphate and CYANEX 921 in kerosene from chloride medium [7]. Extraction equilibrium of Zinc(II) and Cadmium(II) by mixtures of primary amine N1923 and 2-ethylhexyl phosphonic acid di-2-ethylhexyl ester were studied [8]. Synergistic extraction of zinc(II) and cadmium(II) with mixtures of primary amine N1923 and neutral organophosphorous derivatives were carried out [9]. Organophosphorus extractants like CYANEX 302, TBP and trialkylmethyl ammonium chloride has been widely used for the separation and recovery of $\mathrm{Zn}$ (II) from $\mathrm{HCl}$ medium [10]. TBP and various alkyl amine, trialkylphosphine oxides, and tributylphosphine sulfides are used and concluded that diisotridecylamine gives high degree of selectivity of extraction followed by $N$-lauryl- $N$-trialkylmethylamine (Amberlite-LA-2) [11]. The extraction of zinc from chloride medium by mixture of primary amine N1923 and CYANEX 272 (HA). The synergistic effect was observed and the extracted species was found to be $\left(\mathrm{RNH}_{3} \mathrm{Cl}\right) \cdot \mathrm{ZnClA}$ instead of $\mathrm{ZnA}_{2} \cdot 2 \mathrm{HA}$ that was extracted by CYANEX 272 alone [12].

Extraction and determination of zinc are evaluated from study of the effect of $\mathrm{pH}$, sodium salicylate concentration and triphenylphosphine oxide concentration [13]. Extraction of zinc was carried out using the Nn-hexylaniline as an extractant [14].

The present work has therefore been undertaken to obtain some information on the synergistic extraction of zinc (II) from thiocyanate and sulphuric acid media using synergistic mixture of N-n-octylaniline and trioctylamine in xylene. Commercial trioctylamine is used while N-n-octylaniline is synthesized by known method and used. A novel method is proposed for the extractive separation and determination of zinc in the presence of a large number of elements. 


\section{Experimental}

\section{II.1 Reagents}

N-n-octylaniline: The amine was synthesized and purified by distillation [15].

Trioctylamine (TOA) (Spectrochem) is used.

Synergistic mixture of N-n-octylaniline and Trioctylamine solution: The solution (\% v/v) was prepared by taking equal volume of each in xylene having approximate isomeric composition, o-xylene $-10 \%$, $\mathrm{m}$-xylene and p-xylene $45 \%$ each.

Zinc solution: The stock solution of zinc was prepared by dissolving a suitable amount of zinc sulphate heptahydrate in dimineralised water and to it add $5 \mathrm{ml}$ of concentrated sulphuric acid and diluting it to $250 \mathrm{ml}$ with dimineralised water. The solution was standardized complexometrically. It contained $5 \mathrm{mg}$ zinc per $\mathrm{ml}$. The zinc solution of $0.5 \mathrm{mg} / \mathrm{ml}$ was prepared by appropriate dilution.

Thorium solution: A $0.01 \mathrm{M}$ solution was prepared by using thorium nitrate pentahydrate. $0.002 \mathrm{M}$ Thorium solution was prepared by appropriate dilution.

Acetate Buffer solution: A solution was prepared by dissolving $27.2 \mathrm{gm}$ of sodium acetate trihydrate in $400 \mathrm{ml}$ dimineralised water, adding $17 \mathrm{ml}$ of glacial acetic acid and diluting it to one litre.

EDTA solution: 0.01M solution was prepared by dissolving $3.722 \mathrm{~g}$ disodium salt of EDTA in $1000 \mathrm{ml}$ demineralised water. 0.002M EDTA was prepared by appropriate dilution.

All chemicals used were of analytical reagent grade.

\section{II.2 Procedure}

To an aliquot of solution containing $0.5 \mathrm{mg} / \mathrm{ml}$ of zinc, required quantity of sulphuric acid and potassium thiocyanate solution was added to make the concentration of $0.1 \mathrm{M}-7.0 \mathrm{M}$ and $0.01 \mathrm{M}-2.0 \mathrm{M}$ respectively in a volume of $10 \mathrm{ml}$. The solution was shaken and swirled in a $125 \mathrm{ml}$ separating funnel with $10 \mathrm{ml}$ mixture of $\mathrm{N}$-n-octylaniline and trioctylamine $(0.5-1 \%)$ having volume ratio (1:1) in xylene for 3 minutes. The two layers were allowed to separate. The organic phase was stripped twice with $25 \mathrm{ml}$ of acetate buffer for 3 minutes. The amount of zinc in stripped solution was determined complexometrically [16], by adding excess of $0.002 \mathrm{M}$ EDTA and back titrating against $0.002 \mathrm{M}$ thorium nitrate using xylenol orange indicator. The endpoint is yellow to red.

\section{Results and Discussion}

III.1 Effect of the concentration of synergistic mixture and sulphuric acid on $\mathrm{Zn}$ (II) extraction.

Zinc was extracted using varying concentrations of synergistic mixture of $\mathrm{N}$-n-octylaniline and Trioctylamine $(0.5-1.0 \%)$, sulphuric acid $(0.1-7 \mathrm{M})$ and potassium thiocyanate $(0.01-2.0 \mathrm{M})$ (Refer Tables 1 , 2 and 3, Fig. 1 and 2). It was observed that the quantitative extraction of zinc could be attained at the concentrations $1 \%$ of the synergistic mixture and at $2.5 \mathrm{M}$ sulphuric acid and $0.25 \mathrm{M}$ potassium thiocyanate.

III.2 Effect of variation in the concentration of amines in the synergistic mixture on the $\mathrm{Zn}$ (II) extraction Variation in concentration of amines in the mixture was carried out (Refer Table $4 \& 5$ and Fig. $3 \& 4$ ). It was observed that the quantitative extraction of zinc could be attained at the $1 \%$ of synergistic mixture (mixture of $0.5 \% \mathrm{~N}$-n-octylaniline and $0.5 \%$ Trioctylamine) in xylene. Increase in concentration of either of the amine, results into decrease in extraction.

\section{III.3 Effects of various diluents on extraction of $\mathrm{Zn}$ (II)}

Various solvents such as xylene, toluene, benzene, chloroform, carbon tetrachloride and nitrobenzene were used as diluents for synergistic mixture of $\mathrm{N}$-n-octylaniline and Trioctylamine. It was noted that non-polar diluents were more efficient. The clear phase separation was achieved by using xylene. Thus xylene is preferred as diluents throughout the work. (Refer Table 6).

\section{III.4 Enrichment study}

The extraction was quantitative when the aqueous to organic volume ratio was up to $3: 1$ and extraction of Zn (II) was decreased beyond it (Refer Table 7). Extraction equilibrium was reached within 3 minutes. There was no adverse effect on the extraction of zinc by increase in extraction and stripping period.

\section{III.5 Nature of extracted species}

The investigation of the ion association complex of zinc, thiocyanate, sulphuric acid and synergistic mixture of N-n-octylaniline and trioctylamine was carried out from the plots of $\log \mathrm{D}$ vs. $\log$ [N-n-octylaniline and trioctylamine] (Refer Fig. 5). The slopes obtained at $0.03 \mathrm{M}, 0.1 \mathrm{M}, 0.15 \mathrm{M}$ and $1.5 \mathrm{M}$ of potassium thiocyanate are $2.5,2.0,1.9$ and 2.2 respectively indicating that metal to amine ratio in the extracted species is 1:2. Hence, the extracted species would be probably $\left[\left(\mathrm{RRNH}_{2}{ }^{+}\right)_{2} \mathrm{Zn}(\mathrm{SCN})_{4}{ }^{2-}\right]$ and $\left[\left(\mathrm{R}_{3} \mathrm{NH}\right)_{2}{ }^{+} \mathrm{Zn}(\mathrm{SCN})_{4}{ }^{2-}\right]$ 


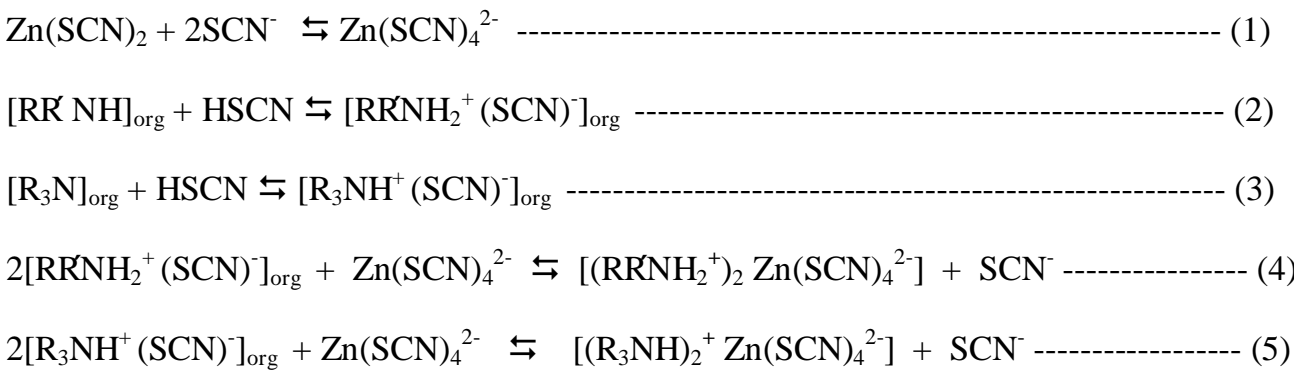

\section{III.6 Effect of foreign ions}

The solutions containing $0.5 \mathrm{mg}$ of zinc (II) (in final solution) and varying amounts of diverse ions were prepared and the content of zinc was determined after extraction. The following ions present/in $\mathrm{mg} / \mathrm{did}$ not cause any interference: acetate, ascorbate, succinate, oxalate, thiourea/100/, tartarate, phosphate/50/, citrate/25/, $\mathrm{Mg}$ (II)/35/, $\mathrm{Mn}$ (II)/40/, $\mathrm{Cr}$ (III)/20/, $\mathrm{Hg}(\mathrm{II}) / 20 /, \mathrm{Ni}(\mathrm{II}) / 10 /, \mathrm{Ce}(\mathrm{II}) / 10 /, \mathrm{As}(\mathrm{III}) / 5 /, \mathrm{Zr}(\mathrm{IV}) / 20 /$. However, the interference can be removed by masking. Th(IV) and $\mathrm{Co}(\mathrm{II})$ were masked with oxalate/100, $\mathrm{Bi}$ (III) and $\mathrm{Cu}(\mathrm{II})$ were masked with thiourea/100/, Fe(III) with ascorbate/100/, Sn(II) with citrate/25/ and Cd(II) with tartarate/50/ (Refer Table 8).

\section{III.7 Applications}

The separation and estimation of zinc from pharmaceutical product and synthetic mixtures was successfully carried out using the developed method. The results obtained indicate that the method is suitable for the extractive separation and estimation of zinc.

\section{III.7.1 Zinc in synthetic mixtures}

Synthetic mixtures containing zinc along with various elements were prepared. The proposed method was applied to the extraction and separation of zinc from the mixtures. The results of analysis showed that $\mathrm{Zn}$ (II) could be separated and determined from synthetic multi-component mixtures. (Refer Table 9)

\section{III.7.2 Analysis of Zinc in pharmaceutical product}

\section{III.7.2.1 Calcimax Syrup (Calcium Syrup)}

A $10 \mathrm{ml}$ syrup was dissolved in perchloric acid containing small amount of nitric acid. This is subjected to evaporation to dryness. The small amount of perchloric acid is added and evaporated to dryness. The residue obtained was leached with distilled water and diluted to $100 \mathrm{ml}$ with distilled water. An aliquot was taken for extraction and estimation of zinc was carried out by recommended procedure. The average of five results is reported (Refer Table 10).

\section{III.7.2.2 Folinz Tablet}

A tablet was dissolved in perchloric acid containing small amount of nitric acid. This is subjected to evaporation to dryness. The small amount of perchloric acid is added and evaporated to dryness. The residue obtained was leached with distilled water and diluted to $100 \mathrm{ml}$ with distilled water. An aliquot was taken for extraction and estimation of zinc was carried out by recommended procedure. The average of five results is reported (Refer Table 10).

\section{Figures and Tables}

Table - 1: Effect of different concentration of synergistic mixture of $\mathrm{N}$-n-octylaniline and Trioctylamine on $\mathrm{Zn}$ (II) distribution ratio (at $2.5 \mathrm{M} \mathrm{H}_{2} \mathrm{SO}_{4}$ and $0.25 \mathrm{M} \mathrm{KSCN}$ )

\begin{tabular}{lll}
\hline $\begin{array}{l}\text { N-n-octylaniline and } \\
\text { Troctylamine, \% }\end{array}$ & $\begin{array}{c}\text { Extraction } \% \\
\text { Ratio, D }\end{array}$ & Distribution \\
\hline 0.50 & 92.50 & 12.33 \\
0.75 & 95.00 & 19.0 \\
1.00 & 99.80 & 499 \\
\hline
\end{tabular}


Liquid-Liquid Extraction And Separation of Zinc (II) With Synergistic Mixture of N-N-Octylaniline

Table - 2: Effect of different concentration of potassium thiocyanate on distribution of $\mathrm{Zn}$ (II) (at $1.0 \%$ synergistic mixture of $\mathrm{N}$-n-octylaniline and Trioctylamine in xylene) keeping 2.5M Sulphuric acid constant.

\begin{tabular}{lll}
\hline $\begin{array}{l}\mathrm{KSCN}, \mathrm{M} \\
\text { Ratio, D }\end{array}$ & Extraction $\%$ & Distribution \\
\hline 0.01 & & \\
0.03 & 67.50 & 2.0769 \\
0.05 & 77.50 & 3.4444 \\
0.07 & 80.00 & 4.0000 \\
0.10 & 85.00 & 5.6667 \\
0.13 & 92.50 & 12.3333 \\
0.15 & 95.00 & 19.0000 \\
0.17 & 96.25 & 25.6667 \\
0.20 & 99.80 & 499 \\
0.25 & 99.80 & 499 \\
0.30 & 99.80 & 499 \\
0.35 & 99.80 & 499 \\
0.40 & 99.80 & 499 \\
0.45 & 97.50 & 39.0000 \\
0.50 & 95.00 & 19.0000 \\
0.70 & 95.00 & 19.0000 \\
1.00 & 95.00 & 19.0000 \\
1.50 & 95.00 & 19.0000 \\
2.00 & 95.00 & 19.0000 \\
& 95.00 & 19.0000 \\
\hline
\end{tabular}

Table - 3: Effect of different concentration of sulphuric acid on distribution of Zn (II) (at $1.0 \%$ synergistic mixture of $\mathrm{N}$-n-octylaniline and Trioctylamine in xylene) keeping $0.25 \mathrm{M}$ potassium thiocyanate constant.

\begin{tabular}{lll}
\hline $\begin{array}{l}\mathrm{H}_{2} \mathrm{SO}_{4}, \mathrm{M} \\
\text { Ratio, D }\end{array}$ & Extraction $\%$ & Distribution \\
\hline 0.10 & & \\
0.50 & 97.5 & 7.0000 \\
1.00 & 90.00 & 9.0000 \\
1.50 & 92.50 & 12.3333 \\
2.00 & 95.00 & 19.0000 \\
2.50 & 97.50 & 39.0000 \\
3.00 & 99.80 & 499 \\
3.50 & 99.80 & 499 \\
4.00 & 99.80 & 499 \\
4.50 & 97.50 & 39.0000 \\
5.00 & 95.00 & 19.0000 \\
5.50 & 92.50 & 12.3333 \\
6.00 & 90.00 & 9.0000 \\
6.50 & 87.50 & 7.0000 \\
7.00 & 85.00 & 5.6667 \\
& 82.50 & 4.7143 \\
\hline
\end{tabular}

Table - 4: Effect of variation in the concentration of amines in the synergistic mixture on the $\mathrm{Zn}$ (II) extraction $($ Concentration of Trioctylamine $=0.50 \%)$

\begin{tabular}{lr}
\hline N-n-octylaniline, \% & \% Extraction \\
\hline 0.1 & 90.00 \\
0.2 & 92.50 \\
0.3 & 95.00 \\
0.4 & 97.50 \\
0.5 & 99.80 \\
0.6 & 97.50 \\
0.7 & 95.00 \\
0.8 & 92.50 \\
0.9 & 90.00 \\
1.0 & 87.50
\end{tabular}


Liquid-Liquid Extraction And Separation of Zinc (II) With Synergistic Mixture of N-N-Octylaniline

Table - 5: Effect of variation in the concentration of amines in the synergistic mixture on the $\mathrm{Zn}$ (II) extraction (Concentration of N-n-octylaniline $=0.50 \%$ )

\begin{tabular}{ll}
\hline Trioctylamine, \% & $\%$ Extraction \\
\hline 0.1 & 87.50 \\
0.2 & 90.00 \\
0.3 & 95.00 \\
0.4 & 97.50 \\
0.5 & 99.80 \\
0.6 & 95.00 \\
0.7 & 90.00 \\
0.8 & 85.00 \\
0.9 & 80.00 \\
1.0 & 75.00 \\
\hline
\end{tabular}

Table - 6: Effects of various diluents on extraction of zinc (II)

\begin{tabular}{lll}
$\begin{array}{l}\text { Diluent's } \\
\text { Ratio, D }\end{array}$ & Extraction \% & Distribution \\
\hline Xylene & & \\
Carbontetra chloride & 99.80 & 499 \\
Benzene & 99.80 & 499 \\
Toluene & 99.80 & 499 \\
Chloroform & 99.50 & 199 \\
Nitrobenzene & 95.50 & 21.2222 \\
& 40.50 & 0.6807
\end{tabular}

Table - 7: Enrichment study

\begin{tabular}{cc}
\hline Aqueous to Organic phase & \% Extraction \\
\hline $1: 1$ & 99.80 \\
$2: 1$ & 99.80 \\
$3: 1$ & 99.80 \\
$4: 1$ & 97.50 \\
$5: 1$ & 95.00 \\
$10: 1$ & 92.50 \\
\hline
\end{tabular}

Table - 8: Effect of diverse ions

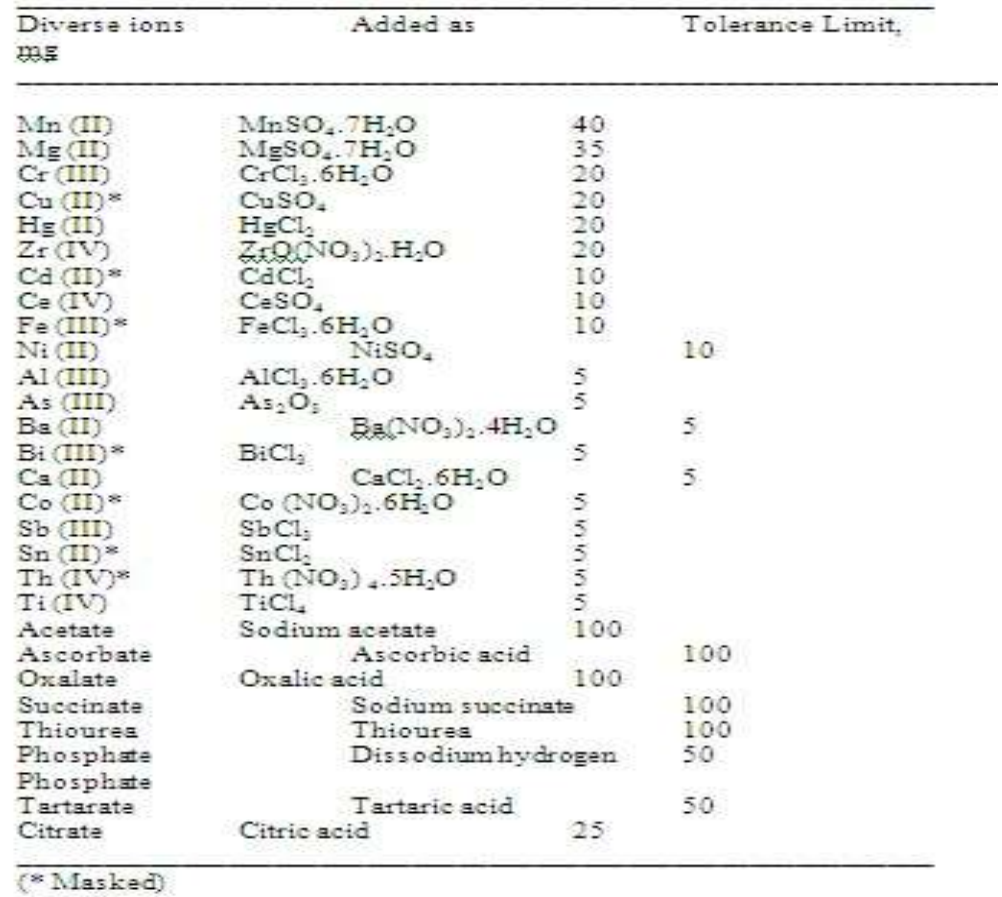




\begin{tabular}{ll}
\hline Composition of mixture, mg & Extraction \% \\
\hline $\mathrm{Cr}(\mathrm{III})=2, \mathrm{Zn}(\mathrm{II})=0.5, \mathrm{Cd}(\mathrm{II})=2$ & 99.80 \\
$\mathrm{Mn}(\mathrm{II})=2, \mathrm{Zn}(\mathrm{II})=0.5, \mathrm{As}(\mathrm{II})=2$ & 99.80 \\
$\mathrm{X} \mathrm{g}(\mathrm{II})=5, \mathrm{Zn}(\mathrm{II})=0.5, \mathrm{Ca}(\mathrm{IV})=5$ & 99.80 \\
$\mathrm{Zn}(\mathrm{IV})=2, \mathrm{Zn}(\mathrm{I})=0.5, \mathrm{Fe}(\mathrm{III})=2$ & 97.50 \\
$\mathrm{Hg}(\mathrm{II})=5, \mathrm{Zn}(\mathrm{I})=0.5, \mathrm{Bi}(\mathrm{III})=5$ & 97.50 \\
\hline
\end{tabular}

Table - 10: Analysis of pharmaceutical samples

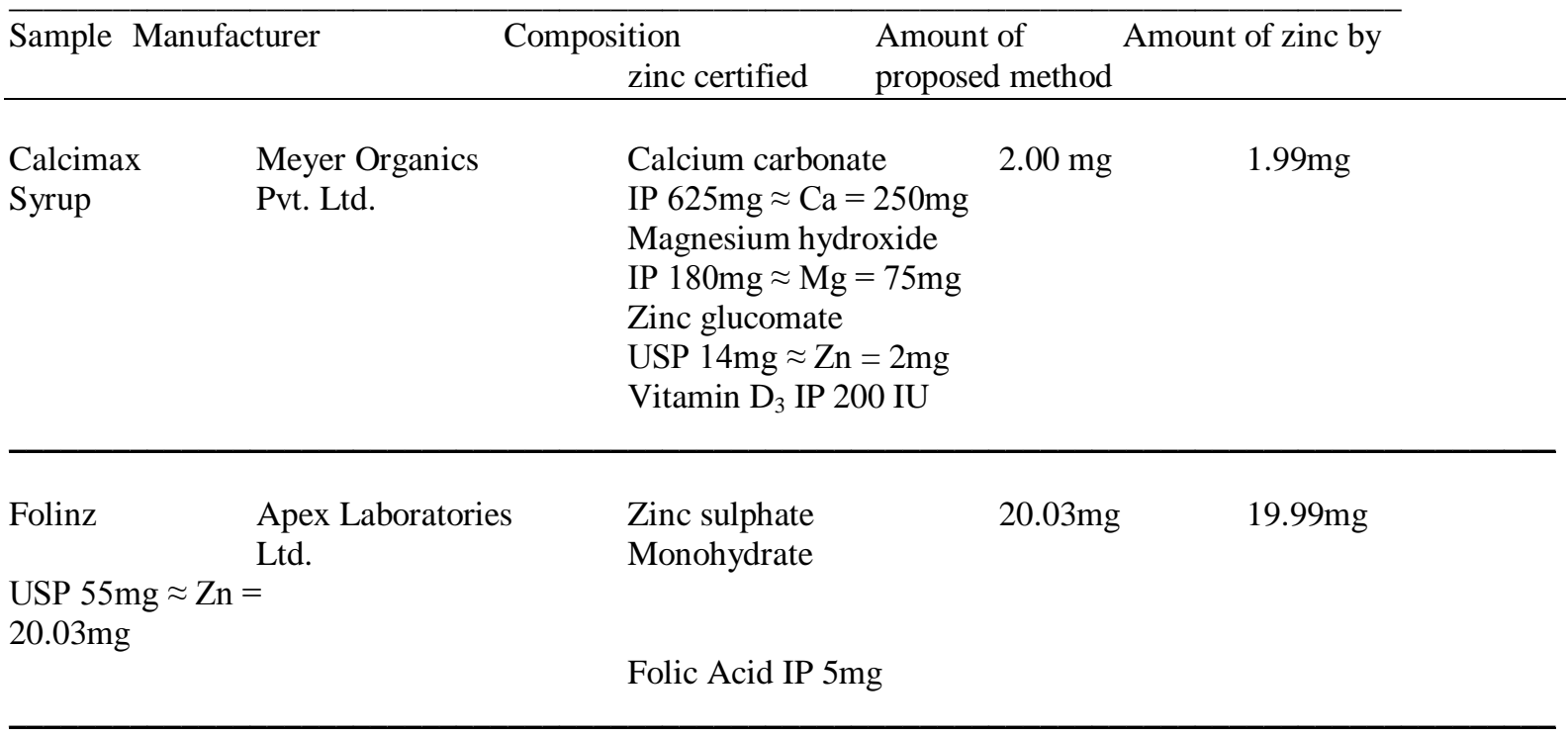

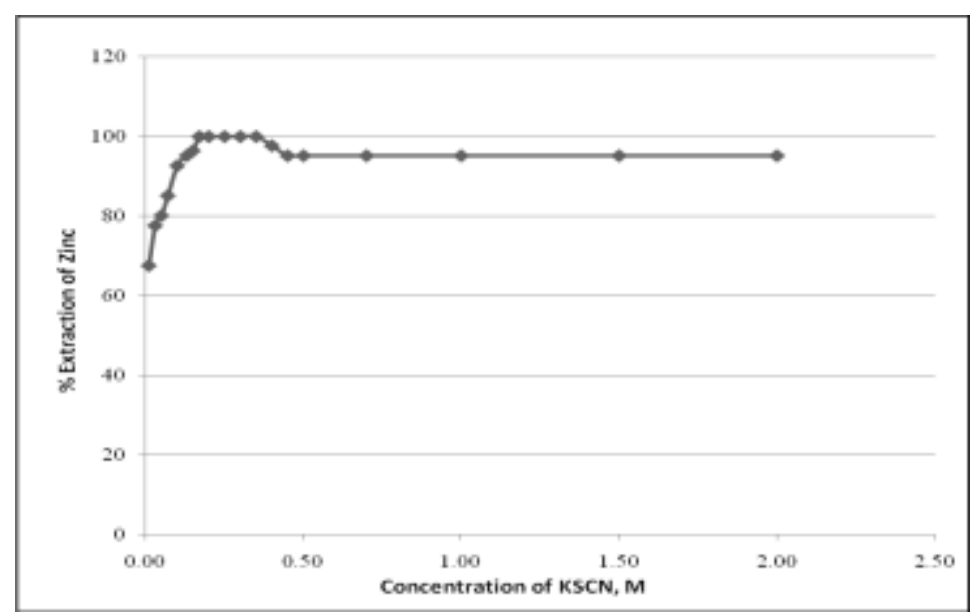

Fig. 1: Extraction behavior of Zinc (II) with 1\% synergistic mixture of N-n-octylaniline and Trioctylamine in xylene as a function of thiocyanate at $2.5 \mathrm{M}$ sulphuric acid. 


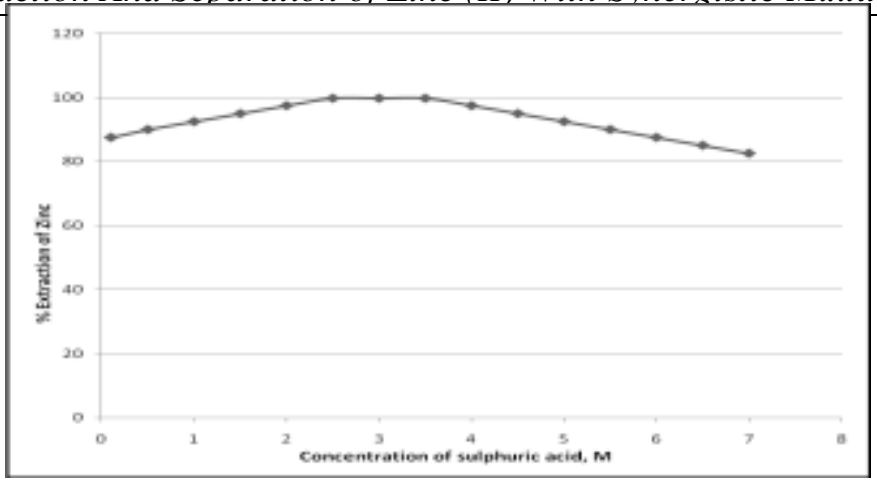

Fig. 2: Extraction behavior of Zinc (II) with synergistic mixture of N-n-octylaniline and Trioctylamine in xylene as a function of concentration of sulphuric acid at $0.25 \mathrm{M}$ potassium thiocyanate.

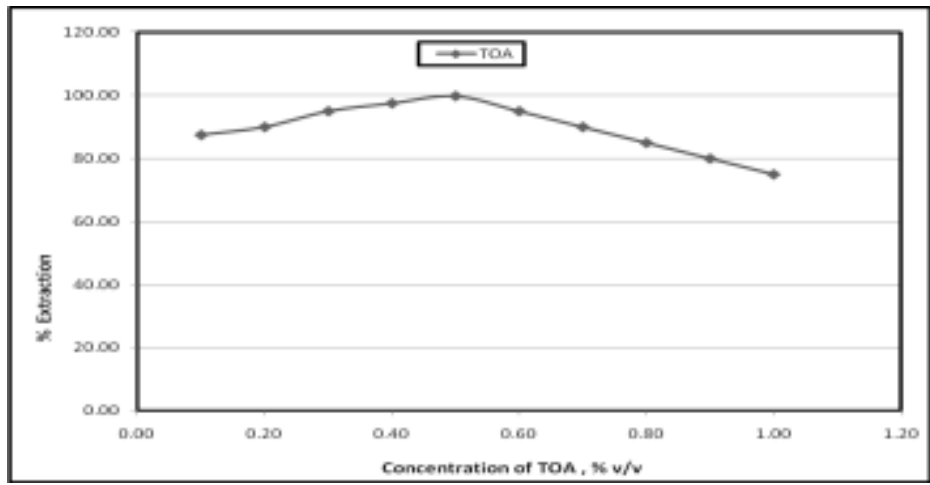

Fig. 3: Extraction behavior of Zinc (II) at fixed concentration of $\mathrm{N}$-n-octylaniline $(0.5 \%)$, by varying the concentration of Trioctylamine (TOA).

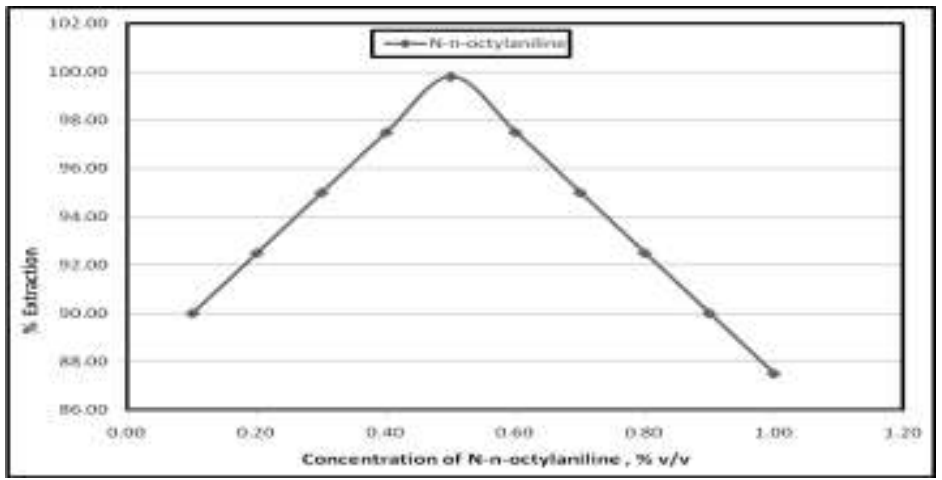

Fig. 4: Extraction behavior of Zinc (II) at fixed concentration of Trioctylamine (TOA) $(0.5 \%)$, by varying the concentration of $\mathrm{N}$-n-octylaniline.

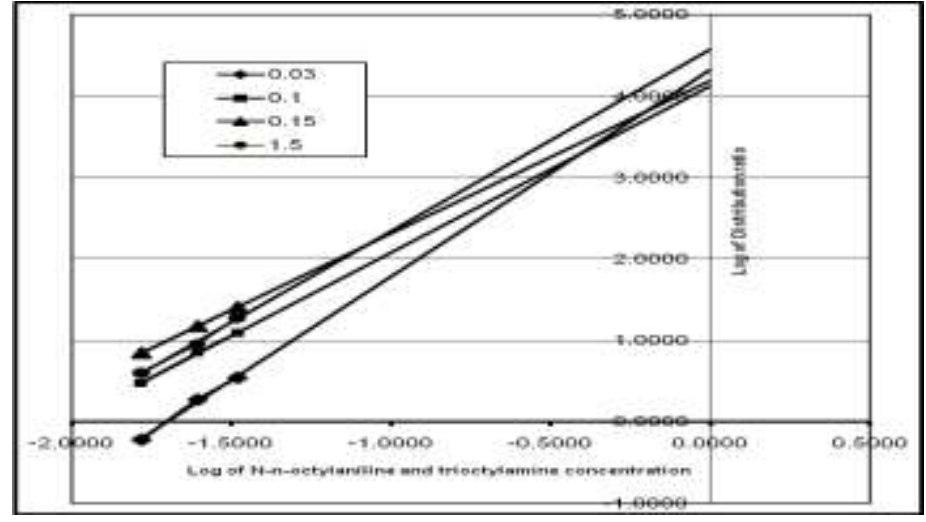

Fig. 5: Distribution Ratio of Zinc (II) as function of synergistic mixture of N-n-octylaniline and Trioctylamine concentration at $0.03,0.1,0.15$ and $1.5 \mathrm{M}$ potassium thiocyanate concentration. 


\section{Conclusion}

The synergism is observed in the mixture of $\mathrm{N}$-n-octylaniline and Trioctylamine due to which quantitative extractions are possible at lower concentrations of extractant in comparison with the use of single extractant. So the method permits the quantitative extraction of Zn (II) from thiocyanate medium.

\section{References}

[1] M. Regel, A. M. Sastre and J. Szymanawski, Environ. Sci. Technol. 35 (2001), pp. 630)

[2] G. N. Mulik, S. R. Kuchekar and M. B. Chavan, Indian J. Chem. Sect. A: Inorg., Bio-inorg., Phys., Theor., Anal. Chem. 1986, 25A, 1073

[3] S. K. Sahoo, Talanta, 1991, 38, 789

[4] C. P. Vibhute, Indian J. Chem. Sect A: Inorg., Bio-inorg., Phys., Theor., Anal. Chem. 1993, 32,1006

[5] M. S. Bhatti and Shamasud-Zuha, J. Radioanal. Chem., 1981, Vol. 62, No. 1-2, 23-29

[6] S. R. Joshi, P. K. Srivastava and S. N. Tandon, J. Radioanal. Chem., 1973, Vol. 13, No. 343 - 347

[7] S. I. El Dessouky, Y. A. El-Nadi, I. M. Ahmed, E. A. Saad and J. A. Daoud, Chem. Eng. and Processing Vol. 47, Issue 2, Feb 2008, 177-183

[8] Jia Qiong, Bi Lihua and Shang Qingkun, Ind. Eng. Chem. Res., 2003, 42 (18), pp 4223-4227

[9] Luo Fang, Li Deqian and Wei Pinghui, Hydrometallurgy Volume 73, Issues 1-2, April 2004, Pages 31-40

[10] K. Schurgerl, A. Larm and M. Guodorf, Proc. ISEC'96, vol. 2 Melbourne, Australia (1996), p. 1543

[11] B. K. Tait, Solv. Extr. Ion Exch. 10 (1992), p. 799

[12] C. Niu, D. Li and Q. Jia, Solv. Extr. Ion Exch. 20 (6) (2002), pp. 751-764

[13] Bhanu Raman and V. M. Shinde, Talanta, Volume 36, Issue 4, April 1989, Pages 469-472

[14] N. B. Kadam-Patil, Rakesh. B. Thorat and A. S. Burungale, Rasayan J. Chem; Vol. 2, No. 4 (2009), 953-959

[15] Z. G. Gardlund, R. J. Curtis and G. W. Smith, Liquid Crystals Ordered Fluids 2 (1973) 541

[16] A. I. Vogel, A Text book of Quantitative Inorganic Analysis $4^{\text {th }}$ ed, ELBS, 1978, P. 325. 